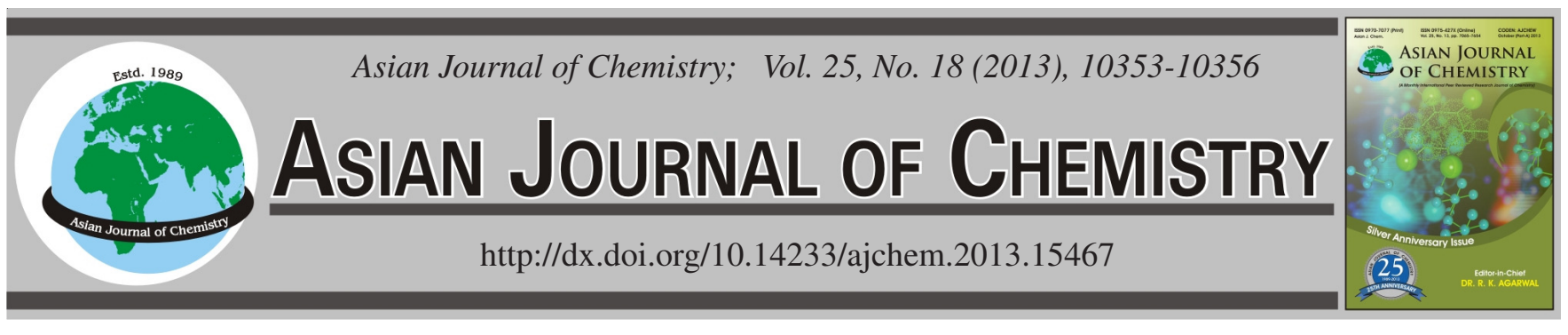

\title{
Synthesis of 5-Benzylidine-3- $\alpha$-carboxy Ethyl Rhodanines and Study of their Anticancer Activity Against HeLa Cell Lines and Antibacterial Activity Against MRSA
}

\author{
KAVERI Sundaram and SubBan Ravi*
}

Department of Chemistry, Karpagam University, Coimbatore-641 021, India

*Corresponding author: E-mail: ravisubban@ rediffmail.com

Seven novel 5-benzylidine-3- $\alpha$-carboxy ethyl rhodanines were synthesized and evaluated for their in vitro anticancer activity against HeLa cell line by MTT assay method and antibacterial activity against Escherichia coli and Bacillus cereus by MIC method. The antibacterial activity was also evaluated against multidrug-resistant Staphylococcus aureus (MRSA). The synthesized compounds were characterized by IR, UV, ${ }^{1} \mathrm{H},{ }^{13} \mathrm{C}$ and MS spectral data. Among the synthesized compounds, $\mathbf{3 b}$ was found to be more potent with HeLa cancer line with an $\mathrm{IC}_{50}$ value of $22.96 \mu \mathrm{M}$ and $\mathbf{3 f}$ against all the bacteria in the antibacterial activity with an MIC value of $80 \mu \mathrm{g} / \mathrm{mL}$.

Key Words: 3- $\alpha$-Carboxy ethyl rhodanine, MTT assay, Antibacterial activity.

\section{INTRODUCTION}

Human cervical cancer is the most common and critical cancer in women caused by human papilloma virus (HPV). There are over 100 types of human papilloma virus (HPV), many of which infect the genital tract. The genital HPVs can be subdivided into two groups. Low-risk HPV types, such as HPV 6, cause benign warts. In contrast, low-risk HPV types, such as HPV 16 and HPV 18, are associated with cervical cancer ${ }^{1}$. Almost $80 \%$ of the cases occur in low income or developing countries. Till now there are no effective drugs for cervical cancer. Developing an efficient and less toxic anticancer agent is an important and challenging goal in medicinal chemistry. So we need enhance the effective anticancer drugs. Rhodanine scaffold is many biologically active compounds ${ }^{2}$. In our ongoing investigations on rhodanines and have tested for the cytotoxicity properties against leukemic CEM cells. The results suggested that the rhodanine affects the cell viability by inhibiting cell division probably by interfering with DNA replication and induce apoptosis ${ }^{3,4}$. In addition, the rhodanine showed strong antiproliferative activity against human leukemic CEM cells 5 . Rhodanine and related heterocycles can most probably be caused by their affinity to anticancer agents, such as JNK-stimulating phosphate-1 (JSP-1) ${ }^{6}$, tumor necrosis factor ${ }^{7}$, antiapoptotic biocomplex $\mathrm{BCLX}_{\mathrm{L}} \mathrm{BH}_{3}{ }^{8}$ etc. Also these compounds have been reported for their hepatitis C virus NS5B polymerase ${ }^{9}$, capthesin $\mathrm{D}^{10}$, antibacterial ${ }^{11,12}$, antidiabetic ${ }^{13}$, antifungal ${ }^{14}$, antiviral ${ }^{15}$, antiinflammatory ${ }^{16}$ and analgesic activities ${ }^{17}$. So far they were not tested for their anti- cancer activity against cervical cancer cell lines (HeLa). So in the present work we have synthesized seven 5-benzylidene-3$\alpha$-carboxy ethylrhodanine derivatives and screened for their in vitro anticancer activity. Further they were also screened for anti MRSA and antibacterial activity.

\section{EXPERIMENTAL}

The synthesis of the seven new 5-benzylidine-3- $\alpha$-carboxy ethyl rhodanines (3a-g) was illustrated in Scheme-I. The substituted aromatic aldehydes (2a-g) was condensed with 3- $\alpha$-carboxy ethyl rhodanine ${ }^{18}(\mathbf{1})$ via knoevenagal condensation ${ }^{19}$ afforded the 2-(5-benzylidene-2-thiaxo-4-thiazolidin-3yl) propanoic acids (3a-g) (Table-1). In the IR spectrum, the desired compounds showed broad band in the region $3400-3000 \mathrm{~cm}^{-1}$ due to the presence of hydroxyl group and strong band at 1730 $\mathrm{cm}^{-1}$ for $\mathrm{C}=\mathrm{O}$. In the ${ }^{1} \mathrm{H}$ NMR spectral data of the compound 3a methyl proton appeared in the up field region at $\delta 1.55(\mathrm{~d}$, $3 \mathrm{H}, \mathrm{H}-1^{\prime}, J=7.2 \mathrm{~Hz}$ ) and a quateret signal at $\delta 5.60(\mathrm{q}, 1 \mathrm{H}$, $J=7.2 \mathrm{~Hz}$ ) for $\mathrm{H}-2$ '. The aromatic protons appeared in the region at $\delta 6.00-8.00$ as multiplets. In addition ${ }^{13} \mathrm{C}$ NMR spectra the peak at $\delta 13.00$ and $\delta 52.00$ are due to methyl (C-1') and methine $\left(\mathrm{C}-2^{\prime}\right)$ carbon atoms. The carbonyl group (C-3') appeared at $\delta 169.46$ and the ring carbonyl (C-4) at $\delta 165.99$. The signal at $\delta 192.08$ was assigned to the thio carbonyl group (C-2). A cluster of peaks appeared between $\delta 100-160$ are due to aromatic carbons.

Melting points were determined in a XT- 5 digital melting point instrument and are uncorrected. IR spectra were recorded (in $\mathrm{KBr}$ ) on a Shimadzu 360 FT-IR spectrometer. ${ }^{1} \mathrm{H}$ and ${ }^{13} \mathrm{C}$ 


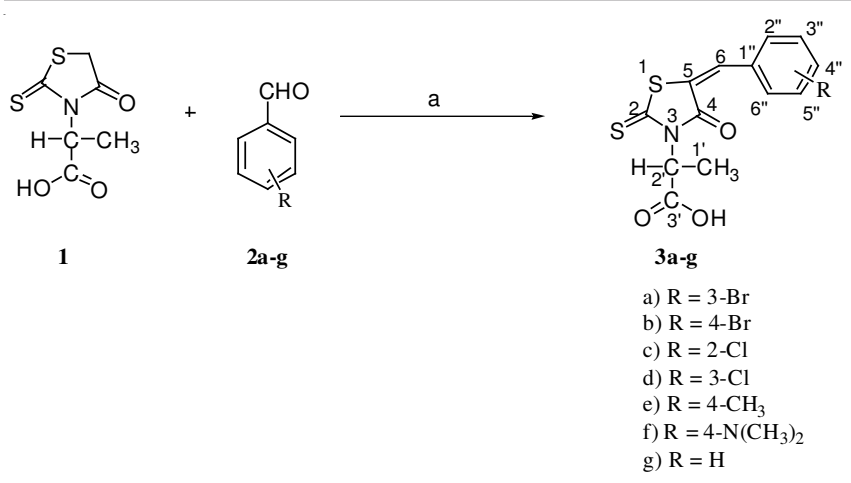

Scheme-I: $\quad$ Synthesis of compounds 3a-g (a) anhydrous $\mathrm{CH}_{3} \mathrm{COONa}$, glacial acetic acid, 4-6 $\mathrm{h}$ reflux

\begin{tabular}{cccc}
\multicolumn{4}{c}{ TABLE-1 } \\
\multicolumn{4}{c}{ CHARACTERIZATION OF THE COMPOUNDS 3a-g } \\
\hline Compounds & $\mathrm{R}$ & m.p. $\left({ }^{\circ} \mathrm{C}\right)$ & Yield $(\%)$ \\
\hline 3a & $3-\mathrm{Br}$ & 248 & 79 \\
3b & $4-\mathrm{Br}$ & 245 & 94 \\
3c & $2-\mathrm{Cl}$ & 234 & 76 \\
3d & $3-\mathrm{Cl}$ & 236 & 72 \\
3e & $4-\mathrm{CH}_{3}$ & 229 & 83 \\
3f & $4-\mathrm{N}_{3} \mathrm{CH}_{3}$ & 232 & 86 \\
3g & $\mathrm{H}$ & 214 & 89 \\
\hline
\end{tabular}

NMR spectra were measured at $400 \mathrm{MHz}$ on a Bruker-400 spectrometer using TMS as internal standard and DMSO- $d_{6}$ as solvent. MS spectra were obtained on a Shimadzu MS instrument. Elemental analyses for C, H, N and S were $\pm 0.04 \%$ of the theoretical values and determined using a Perkin-Elmer 240C Elemental Analyzer.

General procedure for the preparation of compounds 3a-g: To a solution of compound $1(0.001 \mathrm{~mol})$ and the respective aldehydes (2a-f) in glacial acetic acid were added anhydrous sodium acetate $(0.001 \mathrm{~mol})$. The reaction mixture was stirred under reflux for 4-6 $\mathrm{h}$ and then poured into icecold water. The precipitate was filtered, washed with water and dried. Spectral data of each compound are given below.

2-[5-(3-Bromobenzylidene)-4-oxo-2-thioxothiazolidin3-yl]propanoic acid (3a): UV $\lambda_{\max }(\mathrm{nm})$ : 374.00; IR ( $\mathrm{KBr}$, $\left.\mathrm{V}_{\max }, \mathrm{cm}^{-1}\right)$ : 3400-2500 (br. band, OH), $1695(\mathrm{C}=\mathrm{O}), 1602$ $(\mathrm{C}=\mathrm{C}) ;{ }^{1} \mathrm{H}$ NMR (DMSO- $\left.d_{6}\right): \delta 1.55\left(\mathrm{~d}, J=7.2 \mathrm{~Hz}, 3 \mathrm{H}, \mathrm{H}-1^{\prime}\right)$, 5.61 (q, $\left.J=7.2 \mathrm{~Hz}, 1 \mathrm{H}, \mathrm{H}-2^{\prime}\right), 7.49$ (1H, H-5"), 7.59 (1H, H4"), 7.70 (1H, H-6"), 7.79 (s, 1H, H-6), 7.85 (1H, H-2"). ${ }^{13} \mathrm{C}$ NMR (DMSO- $\left.d_{6}\right): \delta 13.33\left(\mathrm{C}-1^{\prime}\right), 52.87$ (C-2'), $122.56(\mathrm{C}-5)$, 123.18 (C-3"), 128.61 (C-6"), 131.38 (C-2"), 131.53 (C-5"), 131.79 (C-4"), 133.51 (C-1"), 135.15 (C-6), 165.99 (C-3"), 169.46 (C-4), 192.08 (C-2). MS: $m / z 370(\mathrm{M}+1)$. Anal. calcd. for $\mathrm{C}_{13} \mathrm{H}_{10} \mathrm{NO}_{3} \mathrm{~S}_{2} \mathrm{Br}$ : C, 41.94; H, 2.71; N, 3.76; S, 17.23; Found (\%): C, 41.90; H, 2.73; N, 3.73; S, 17.26.

2-[5-(4-Bromobenzylidene)-4-oxo-2-thioxothiazolidin3-yl]propanoic acid (3b): UV $\lambda_{\max }(\mathrm{nm})$ : 380.00 ; IR (KBr, $\left.\mathrm{V}_{\max }, \mathrm{cm}^{-1}\right)$ : 3400-2500 (br. band, OH), $1707(\mathrm{C}=\mathrm{O}), 1587$ $(\mathrm{C}=\mathrm{C}) ;{ }^{1} \mathrm{H}$ NMR (DMSO- $\left.d_{6}\right): \delta 1.55\left(\mathrm{~d}, J=7.2 \mathrm{~Hz}, 3 \mathrm{H}, \mathrm{H}-1^{\prime}\right)$, 5.61 (q, $J=7.2 \mathrm{~Hz}, 1 \mathrm{H}, \mathrm{H}-2$ ') 7.57 (d, $J=8.8 \mathrm{~Hz}, 2 \mathrm{H}, \mathrm{H}-3 "$, 5"), 7.75 (dd, $J=8.8 \mathrm{~Hz}, 2 \mathrm{H}, \mathrm{H}-2 ", 6 "), 7.79$ (s, 1H, H-6), ${ }^{13} \mathrm{C}$ NMR (DMSO- $\left.d_{6}\right)$ : $\delta 13.34\left(\mathrm{C}-1^{\prime}\right), 52.82\left(\mathrm{C}-2^{\prime}\right), 122.20(\mathrm{C}-5)$, 124.81 (C-4"), 131.94 (C-3"), 132.28 (C-5"), 132.35 (C-1"), 132.48 (C-6), 166.12 (C-3'), 169.47 (C-4), 192.59 (C-2). MS: $m / z 370(\mathrm{M}+1)$. Anal. calcd. (\%) for $\mathrm{C}_{13} \mathrm{H}_{10} \mathrm{NO}_{3} \mathrm{~S}_{2} \mathrm{Br}: \mathrm{C}, 41.94$; H, 2.71; N, 3.76; S, 17.23; Found (\%): C, 41.96; H, 2.74; N, $3.78 ; \mathrm{S}, 17.24$.

2-[5-(2-Chlorobenzylidene)-4-oxo-2-thioxothiazolidin3-yl]propanoic acid (3c): UV $\lambda_{\max }(\mathrm{nm})$ : 364.50 ; IR (KBr, $\left.v_{\max }, \mathrm{cm}^{-1}\right)$ : 3400-2500 (br. band, OH), $1712(\mathrm{C}=\mathrm{O}), 1595$ $(\mathrm{C}=\mathrm{C}) ;{ }^{1} \mathrm{H}$ NMR (DMSO- $\left.d_{6}\right): \delta 1.69\left(\mathrm{~d}, J=7.2 \mathrm{~Hz}, 3 \mathrm{H}, \mathrm{H}-1^{\prime}\right)$, 5.82 (q, $\left.J=7.2 \mathrm{~Hz}, 1 \mathrm{H}, \mathrm{H}-2^{\prime}\right), 7.38$ (2H, H-4", 5"), 7.48 (2H, H-3", 6"), 8.10 (s, 1H, H-6). ${ }^{13} \mathrm{C}$ NMR (DMSO- $d_{6}$ ): $\delta 13.55$ (C-1'), 52.76 (C-2'), 124.90 (C-5), 127.43 (C-5"), 129.26 (C-4"), 129.75 (C-6"), 130.65 (C-3"), 131.64 (C-2"), 131.71 (C-1"), 136.40 (C-6), 166.32 (C-3'), 173.65 (C-4), 192.25 (C-2). MS: $m / z 326(\mathrm{M}+1)$. Anal. calcd. $(\%)$ for $\mathrm{C}_{13} \mathrm{H}_{10} \mathrm{NO}_{3} \mathrm{~S}_{2} \mathrm{Cl}$ : C, 47.63; H, 3.07; N, 4.27; S, 19.56; Found (\%): C, 47.62; H, 3.11; N, $4.25 ; \mathrm{S}, 19.57$.

2-[5-(3-Chlorobenzylidene)-4-oxo-2-thioxothiazolidin3-yl]propanoic acid (3d): UV $\lambda_{\max }(\mathrm{nm})$ : 373.00; IR (KBr, $\left.V_{\max }, \mathrm{cm}^{-1}\right): 3400-2500$ (br. band, OH), $1695(\mathrm{C}=\mathrm{O}), 1604$ $(\mathrm{C}=\mathrm{C}) ;{ }^{1} \mathrm{H}$ NMR (DMSO- $\left.d_{6}\right): \delta 1.54(\mathrm{~d}, J=7.2 \mathrm{~Hz}, 3 \mathrm{H}, \mathrm{H}-$ 12), 5.62 (q, J=7.2 Hz, 1H, H-2'), 7.55 (2H, H-2", 4"), 7.60 (1H, H-6"), 7.67 (1H, H-5"), 7.91 (s, 1H, H-6). ${ }^{13} \mathrm{C}$ NMR (DMSO- $\left.d_{6}\right)$ : $\delta 13.52$ (C-1'), 52.91 (C-2'), 125.04 (C-5), 128.22 (C-6"), 128.36 (C-2"), 129.51 (C-4"), 130.49 (C-5"), 130.69 (C-3"), 132.52 (C-1"), 134.78 (C-6), 165.92 (C-3'), 169.43 (C-4), 192.84 (C-2). MS: m/z $326(\mathrm{M}+1)$. Anal. calcd. (\%) for $\mathrm{C}_{13} \mathrm{H}_{10} \mathrm{NO}_{3} \mathrm{~S}_{2} \mathrm{Cl}$ : C, 47.63; H, 3.07; N, 4.27; S, 19.56; Found (\%): C, 47.67; H, 3.10; N, 4.29; S, 19.55 .

2-[5-(4-Methylbenzylidene)-4-oxo-2-thioxothiazolidin3-yl]propanoic acid (3e): UV $\lambda_{\max }(\mathrm{nm})$ : 364.00 ; IR $(\mathrm{KBr}$, $\left.v_{\max }, \mathrm{cm}^{-1}\right): 3400-2500$ (br. band, OH), $1695(\mathrm{C}=\mathrm{O}), 1585$ $(\mathrm{C}=\mathrm{C}) ;{ }^{1} \mathrm{H}$ NMR (DMSO- $\left.d_{6}\right): \delta 1.55\left(\mathrm{~d}, J=7.2 \mathrm{~Hz}, 3 \mathrm{H}, \mathrm{H}-1^{\prime}\right)$, 2.36 (3H, s, H-7"), 5.60 (q, $\left.J=7.2 \mathrm{~Hz}, 1 \mathrm{H}, \mathrm{H}-2^{\prime}\right), 7.38$ (d, $J=$ $8.0 \mathrm{~Hz}, 2 \mathrm{H}, \mathrm{H}-3 ", 5 "), 7.54$ (d, J=8.0 Hz, 2H, H-2", 6"), 7.78 (s, 1H, H-6). ${ }^{13} \mathrm{C}$ NMR (DMSO- $\left.d_{6}\right): \delta 13.36\left(\mathrm{C}-1^{\prime}\right), 21.13$ (C-7"), 52.76 (C-2'), 120.11 (C-5), 130.07 (C-2", 6"), 130.19 (C-3", 5"), 130.78 (C-1"), 133.82 (C-4"), 141.79 (C-6), 166.23 (C-3'), 169.54 (C-4), 192.89 (C-2). MS: m/z 307 (M + 1). Anal. calcd. (\%) for $\mathrm{C}_{14} \mathrm{H}_{13} \mathrm{NO}_{3} \mathrm{~S}_{2}$ : C, 54.70; H, 4.26; N, 4.56; S, 20.86; Found (\%): C, 54.73; H, 4.29; N, 4.58; S, 20.82.

2-[5-\{4-(Dimethylamino)benzylidene\}-4-oxo-2thioxothiazolidin-3-yl]propanoic acid (3f): $\mathrm{UV} \boldsymbol{\lambda}_{\max }(\mathrm{nm})$ : 459.50 ; IR (KBr, $\left.v_{\max }, \mathrm{cm}^{-1}\right)$ : 3400-2500 (br. band, OH), $1699(\mathrm{C}=\mathrm{O})$, $1570(\mathrm{C}=\mathrm{C}) ;{ }^{1} \mathrm{H}$ NMR (DMSO- $\left.d_{6}\right): \delta 1.53(\mathrm{~d}, J=7.2 \mathrm{~Hz}, 3 \mathrm{H}$, H-1'), 3.04 (6H, s, H-7", 8"), 5.60 (q, J = 7.2 Hz, 1H, H-1'), 6.84 (d, $J=8.8 \mathrm{~Hz}, 2 \mathrm{H}, \mathrm{H}-3 ", 5 "), 7.45$ (d, $J=9.2 \mathrm{~Hz}, 2 \mathrm{H}$, H-2", 6"), 7.66 (s, 1H, H-6). ${ }^{13} \mathrm{C}$ NMR (DMSO-d $)$ ): $\delta 13.43$ (C-1'), 52.60 (C-2'), 112.24 (C-7", 8"), 112.72 (C-5), 135.16 (C-6), 152.09 (C-4"), 166.24 (C-3'), 169.72 (C-4), 192.13 (C2). MS: $m / z 336(\mathrm{M}+1)$. Anal. calcd. (\%) for $\mathrm{C}_{15} \mathrm{H}_{16} \mathrm{~N}_{2} \mathrm{O}_{3} \mathrm{~S}_{2}$ : C, 53.55; H, 4.79; 8.33; S, 19.06; Found (\%): C, 53.58; H, $4.80 ;$ N, 8.30; S, 19.10 .

2-(5-Benzylidine-4-oxo-2-thioxothiozolidine-3-yl)propanoic acid (3g): UV $\lambda_{\max }(\mathrm{nm})$ : 375.50 ; IR $\left(\mathrm{KBr}, \mathrm{v}_{\max }\right.$, $\left.\mathrm{cm}^{-1}\right)$ : 3400-2500 (br. Band, $\left.\mathrm{COOH}\right), 1724(\mathrm{C}=\mathrm{O})$ and 1589 $(\mathrm{C}=\mathrm{C}) ;{ }^{1} \mathrm{H}$ NMR (DMSO- $\left.d_{6}\right): \delta 1.56\left(\mathrm{~d}, J=7.2 \mathrm{H}_{\mathrm{z}}, 3 \mathrm{H}, \mathrm{H}-1{ }^{\prime}\right)$, 5.62 (q, $\left.J=7.2 \mathrm{H}_{\mathrm{z}}, 1 \mathrm{H}, \mathrm{H}-2^{\prime}\right), 3.30$ (s, 1H, H-3'), 7.55 (m, 3H, H-3", 4", 5"), 7.65 (dd, J=7.0 Hz, $2.0 \mathrm{H}_{\mathrm{Z}}, 2 \mathrm{H}, \mathrm{H}-1$ ', 6"), 7.84 (s, 1H, H-6); ${ }^{13} \mathrm{C}$ NMR (DMSO- $\left.d_{6}\right): \delta 13.38\left(\mathrm{C}-1^{\prime}\right), 52.81(\mathrm{C}-$ 2'), 121.46 (C-5), 129.52 (C-2", 6"), 130.67 (C-3", 5"), 131.14 
(C-4"), 132.84 (C-1"), 133.65 (C-6), 166.18 (C-3'), 169.48 (C-4) and $192.98(\mathrm{C}-2)$. MS: $m / z 293(\mathrm{M}+1)$. Anal. calcd. (\%) for $\mathrm{C}_{13} \mathrm{H}_{11} \mathrm{NO}_{3} \mathrm{~S}_{2}$ : C, 53.22; $\mathrm{H}, 3.78 ; \mathrm{N}, 4.77 ; \mathrm{S}, 21.86$; Found (\%): C, 53.23; H, 3.75; N, 4.81; S, 21.88.

\section{RESULTS AND DISCUSSION}

Previously, we reported the synthesis and anticancer evaluation of rhodanine derivatives that possessed 3-ethylrhodanine and benzylidene or alkylidene moieties, among which 3-ethyl5-benzylidene rhodanine (1) (Fig. 1) showed the strongest activity against human leukemic cells ${ }^{3}$. In the present work, as part of our ongoing research, we report the structure-based design using 1 as the lead compound, in which the modification of 1 was focused on reserving the rhodanine moiety, changing the benzylidene moiety by introducing different substituent's into the phenyl ring. This design is aimed to get more optimized structure binding to receptor easily, consequently results in their more potent activity. Moreover the $\mathrm{N}$-ethyl rhodanine is replaced with $\alpha$-methyl carboxy methyl rhodanine is used in the present studies against HeLa cell lines instead of human leukemic cells. Thus, a series of benzylidene rhodanine were synthesized and 7 derivatives were characterized and screened for their anticancer activity.

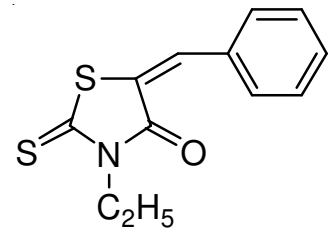

Fig. 1. 3-Ethyl-5-benzylidene rhodanine

The synthesized compounds 3a-g(Table-1) was screened for the in vitro anticancer activity against human cervical cancer cell line HeLa by MTT assay method ${ }^{20}$. All the compounds exhibited the activity. The control compound $\mathbf{3 g}$ showed a moderate activity when compared to the substituted compound 3a-g. Two electron withdrawing groups chloro (2- $\mathrm{Cl}$ and $3-\mathrm{Cl}$ ) and bromo (3-Br and 4-Br) compounds and two electron donating substituent's methyl and dimethyl amino groups in the p-position were taken up for the SAR study. The results suggested that the electron withdrawing groups have more potency than the electron donating groups. The compound $\mathbf{3 b}$ exhibited highest potential against HeLa cell line with an $\mathrm{IC}_{50}$ $22.96 \mu \mathrm{M}$ (Fig. 2). Despite the compound 3a showed less activity than compound $\mathbf{3 b}$, even though both the compounds contain the same electronegative bromo. It shows that more the electro negativity more the activity. This reason may be the position involved to determine the activity. The chloro substituent's 3c and 3d exhibited cytotoxicity above $100 \mu \mathrm{M}$. In the series the two electron donating compounds $\mathbf{3 e}$ and $\mathbf{3 f}$ showed less activity with an $\mathrm{IC}_{50}$ above $100 \mu \mathrm{M}$. The compound 3b exhibited activity comparable to the control.

In addition to this all the synthesized compounds 3a-g were evaluated for the in vitro antibacterial activity with Escherichia coli (gram negative), Bacillus cereus (gram negative) and multidrug-resistant Staphylococcus aureus by serial dilution method ${ }^{21}$ to obtain minimum inhibition concentration (MIC). The results suggested (Table-2) that the compound $\mathbf{3 f}$

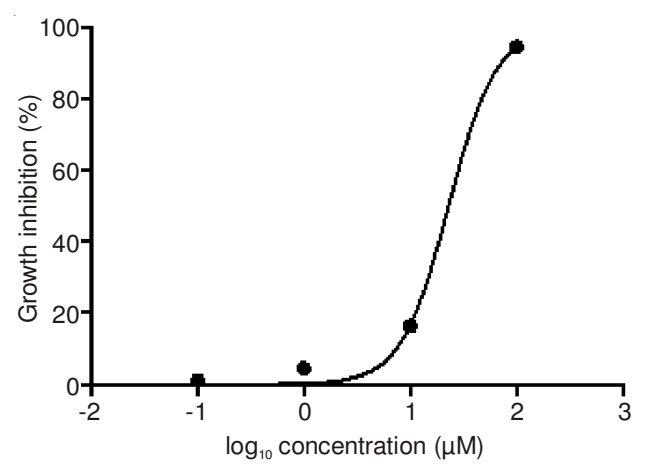

Fig. 2. Cytotoxicity of compound $\mathbf{3 b}$ on $\mathrm{HeLa}$ cell line with an $\mathrm{IC}_{50}$ value of $22.96 \mu \mathrm{M}$

showed resistant in $80 \mu \mathrm{g} / \mathrm{mL}$ concentration against $S$. aureus, $E$. coli and B. sereus. The electron withdrawing group derivatives $\mathbf{3 a}, \mathbf{3 b}, \mathbf{3} \mathbf{c}$ and $\mathbf{3 d}$ showed poor activity against all the strains with the MIC $>160 \mu \mathrm{g} / \mathrm{mL}$. The methyl substituent $3 \mathbf{e}$ also showed moderate activity with all the strains. The compound 3f showed good activity against all the strains. The potency of 3f is marginally less when compared with the control drug Amikacin with an MIC value of $10 \mu \mathrm{g} / \mathrm{mL}$ against all the strains. To last the antibacterial activity the compounds were screened against $S$. aureus, E. coli and B. sereus.

TABLE-2

ANTIBACTERIAL ACTIVITY OF COMPOUND 3a-g BY MIC METHOD AGAINST MULTIDRUG-RESISTANT OF Staphylococcus aureus (GRAM POSITIVE), Escherichia coli (GRAM NEGATIVE) AND Bacillus cereus (GRAM POSITIVE)

\begin{tabular}{cccc}
\hline \multirow{2}{*}{ Compounds } & \multicolumn{3}{c}{ Minimum inhibition concentration (MIC) $\mu \mathrm{g} / \mathrm{mL}$} \\
\cline { 2 - 4 } & MRSA & $\begin{array}{c}\text { E. coli gram } \\
\text { negative }\end{array}$ & $\begin{array}{c}\text { B. cereus gram } \\
\text { positive }\end{array}$ \\
\hline 3a & Nil & 160 & 320 \\
3b & 320 & Nil & 160 \\
3c & 160 & $320>$ & 320 \\
3d & 160 & 160 & 80 \\
3e & 160 & $320>$ \\
3f & 80 & 80 & 320 \\
3g & 320 & 320 & 80 \\
Amikacin & 10 & 10 & 320 \\
\hline
\end{tabular}

The more potent compound $\mathbf{3 f}$ shows less cytotoxic activity which suggests that the compound does not harm the cells.

Since all the compounds exhibited the antibacterial activity they were screened against MRSA. Further it could be concluded that a free carbonyl group seem to be necessary for the anti-bacterial activity against gram-positive strains. The hypothesis that the hydrophobic amino acid substituent's at the N3-position would increase the likelihood of penetration through the bacterial cell wall and therefore potentially improve their antibacterial activity of the compounds.

\section{Conclusion}

In summary, a series of 5-benzylidene- $\alpha$-carboxy ethyl rhodanine derivatives were synthesized and evaluated in vitro anticancer activity against human cervical cancer cell lines HeLa and in vitro antibacterial activity against multidrugresistant $S$. aureus, E. coli and B. sereus pathogens. The compound $\mathbf{3 b}$ showed better cytotoxicity against HeLa cell lines. In antibacterial activity compound $\mathbf{3 f}$ showed good activity with all the strains. 


\section{ACKNOWLEDGEMENTS}

The authors thank to Karpagam University for providing Karpagam University Research Fellowship and DST for financial assistance.

\section{REFERENCES}

1. G. Dell and K. Gaston, Cell Mol. Life Sci., 58, 1923 (2001).

2. T. Tomasic and L.P. Masic, Curr. Med. Chem., 16, 1596 (2009).

3. B.T. Moorthy, S. Ravi, M. Srivastava, K.K. Chiruvella, H. Hamlal, O. Joy and S.C. Raghvan, Bioorg. Med. Chem. Lett., 20, 6297 (2010).

4. S. Ravi, K.K. Chiruvella, K. Rajesh, V. Prabhu and S.C. Raghvan, Eur J. Med. Chem., 45, 2748 (2010).

5. S. Chandrappa, C.V. Kavitha, M.S. Shabuddin, K. Vinaya, C.S. Ananda Kumar, S.R. Ranganatha, S.C. Raghvan and K.S. Rangappa, Bioorg. Med. Chem. Lett., 17, 2576 (2009).

6. N.S. Cutshall, C. O'Day and M. Prezhdo, Bioorg. Med. Chem. Lett., 15, 3374 (2005).

7. P.H. Carter, P.A. Sccherle, J.A. Muckelbauer, M.E. Voss, R.Q. Liu, L.A. Thompson, A.J. Tebben, K.A. Soloman, Y.C. Lo, Z. Li, P. Strzemienski, G. Yang, N. Falahatpisheh, M. Xu, Z. Wu, N.A. Farrow, K. Ramanarayan, J. Wang, D. Rideout, V. Yalamoori, P. Domaille, D.J. Underwood, J.M. Trzskos, S.M. Friedman, R.C. Newton and C.P. Deicco, Proc. Nat. Acad. Sci. USA, 98, 11879 (2001).

8. A. Degterev, A. Lugovskoy, M. Cardone, B. Mulley, G. Wagner, T. Mitchison and J. Yuan, Nat. Cell Biol., 3, 173 (2001).
9. T.T. Talele, P. Arora, S.S. Kulkarni, M.R. Patel, S. Singh, M. Chudayeu and N. Kaushik-Basu, Bioorg. Med. Chem., 18, 4630 (2010).

10. C.A. Whitesitt, R.L. Simon, J.K. Reel, S.K. Sigmund, M.L. Phillips, J.K. Shadle, L.J. Heinz, G.A. Koppel, D.C. Hunden, S.L. Lifer, D. Berry, J. Ray, S.P. Little, X. Liu, W.S. Marshall and J.A. Panetta, Bioorg. Med. Chem. Lett., 6, 2157 (1996).

11. M.X. Song, C.J. Zheng, X.Q. Deng, Q. Wang, S.P. Hou, T.T. Liu, X.L. Xing and H.R. Pio, Eur. J. Med. Chem., 54, 403 (2012).

12. D. Hardej, C.R. Ashby Jr., N.S. Khadtare, S.S. Kulkarni, S. Singh and T.T. Talele, Eur. J. Med. Chem., 45, 5827 (2010).

13. R. Murugan, S. Anbazhagan and S.S. Narayanan, Eur. J. Med. Chem., 44, 3272 (2009).

14. K. Liaras, A. Geronikaki, J. Glamoclija, A. Ciric and M. Sokovi, Bioorg. Med. Chem., 19, 3135 (2011).

15. J.H. Wu, X.H. Wang, Y.H. Yi and K.H. Lee, Bioorg. Med. Chem. Lett., 13, 1813 (2003).

16. S.J. Won, C.T. Liu, L.T. Tsao, J.R. Weng, H.H. Ko, J.P. Wang and C.N. Lin, Eur. J. Med. Chem., 40, 103 (2005).

17. G.S. Viana, M.A. Bandeira and F.J. Matos, Phytomedicine, 10, 189 (2003).

18. S. Wang, Y. Zhao, W. Zhu, Y. Liu, K. Guo and P. Gong, Arch. Pharm. Chem. Life Sci., 345, 73 (2012).

19. C.L. Lee and M.M. Sim, Tetrahedron Lett., 41, 5729 (2000).

20. T. Mosmann, J. Immunol. Methods, 65, 55 (1983).

21. Z.H. Chen, C.J. Zheng, L.P. Sun and H.R. Pio, Eur. J. Med. Chem., 45, 5739 (2010). 